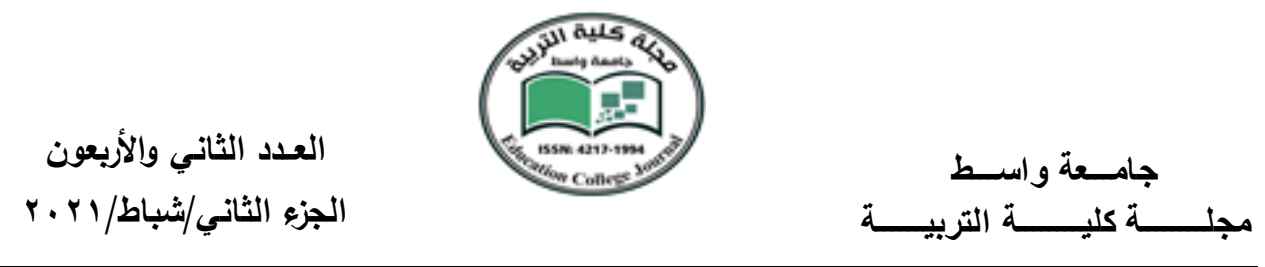

أثر الحجر في تثكيل بنية الرحلة في القصيدة الجاهلية

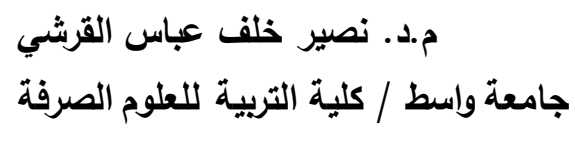

nas eer.abbas@uowasit.edu.iq

ملخص البحث.

يتناول هذا البحث أثر الحجر في تشكيل بنية الرحلة في القصبدة الجاهلية، وطبيعـة الدلالات

التي اتكأ عليها الثـاعر في وصف طبيعة الرحلة ومـا تتطوي عليه من مشـاهد، وقعت تحت طائل

عدسته التصويرية.

فوجد الباحث الحجر حاضـرا في صنفي الرحلة (رحلة الظعائن، ورحلة الشـاعر)، ففي الظعائن

يمثل باعثا للألم؛ حال دون روئة الثـاعر للهوادج الراحلة، وأمَّا مع الثـاعر فقد كان له حضور أكثر ورئر

من الصنف الاول، والسبب أنَّ رحلة الثاعر تضمنت وصف الناقة والثور الوحشي والحمار والظليم،

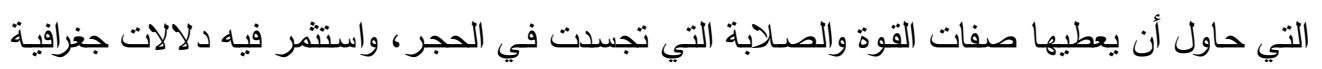
استقاد منها في رسم طريقه وما رافقه فيه من صعوبات.

الكلمات المفتاحية: الحجر، بنية، الرحلة، الظعائن، الثاعر، الناقة، الثور الوحشي،الحمار الوحثي

The effect of stone in shaping the model of the journey in the pre-Islamic poem

L. Dr. Naseer Khalaf Abbas al-Qurashi

\title{
Research Summary.
}

This research deals with the role of stone in shaping the structure of the journey in the poem of ignorance, and the nature of the signs on which the poet relied on to describe the nature of the journey and the implications of the scenes, signed under the use of the lens of imagery.

The poet found the stone present in the two categories of the journey (the voyage of the oppressors, the journey of the poet), in the oppressor represents a painkiller, prevented the poet's vision of the late Haddad, but with the poet has had a presence more than the first category, and the reason that the journey of the poet included description of the camel and the wild bull and donkey Which tried to give them the qualities of strength and hardness embodied in stone, and invested in it geographical indications benefited from in drawing his way and the accompanying difficulties. key words: Stone, structure, the journey, Al-Da'en, the poet, the camel, the wild bull, the zebra 
العدد الثاني والأريعون

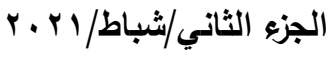

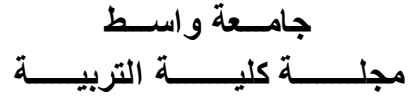

المقدمة :

يعود الاهتمام بغرض الرحلة في القصيدة الجاهلية الى أهمية القصيدة ذاتها، إذ تمثّل تلك القصيدة قمّة الإبداع الذي وصل إليه الثعر الجاهلي، وكذلك قدرتها على استيعاب موضوعات عدة في آن واحد، ثُ إنَّها تعطينا فكرة واضحة عن مستوى وعي الثاعر وإمكاناته الفنية والأدبية، وتطلعنا أيضاً على ثقافة العصر الذي وللت فيه، والرحلة جانب من جوانبها البنائية المهمة، حيث تشهـ تعدداً في الموضوعات وتتوعاً في المشاهد، ولاسيّما فيما بتعلق بطبيعة أشكال الحجر وتجلياته، والحيوانات التي يحتاج الشاعر أن يستدعي معها أشكالا متعدّدة ودلالات كثيرة منه يعبّر من طريقها عن طبيعة تلك الحيوانات القوية والصلبة، وقد قُشِّم البحث على محورين تضمن الأول رحلة الظعائن، وأمَّا المحور الثاني فقد تتاولت فيه رحلة الثاعر التي تتضمن وصف الناقة وما شُبِّهتْ به، أو كان معادلاً لها كثور الوحش والحمار والظليم والنعامة. أثر الحجر في الرحلة تمنّل الرحلة في القصيدة الجاهلية التحول الواقعي والفني في وجود الشاعر؛ إذ إنَّ الشاعر محكوم بأمرين؛ الأول: المكان وأثره في حياة الانسان/الثاعر ؛ وأمَّا الثاني فقد يتعلق بمشاعر الانسان وارتباطه بالآخر سواء أكان أهلا أم حبيبة؛ هذا ما له علاقة بالجانب الواقعي. وأمَّا الجانب الفني فقد يكون مشهر الرحلة نهاية لتراجيديا المقدة الطللية التي شاع فيها الحزن وغمرها الموت والضياع، هذا فضلا عن طبيعتها المشتملة على كثرة المشاهد المختلفة والمتنوعة. وتمثل الرحلة نزوحا عن مشاهد الألم والحسرة ومحاولة في تغيير الواقع؛ فحين "يشتد بالشاعر

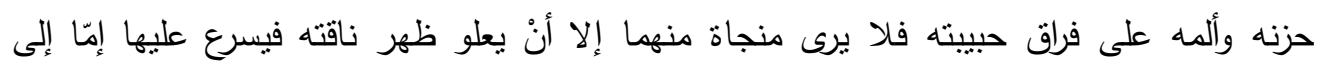
اللحاق بتلك القبيلة المهاجرة وإما إلى الفرار من الديار المهجورة التي هاجت عليه تلك الذكرى الأليمة وعلى كلا الزعمين يتيح له هذا التخلص أنْ ينتقل إلى وصف ناقته وأسفاره على هذه الناقة" (النويهي، د.محمد. الشعر الجاهلي منهج في دراسته وتقويمه://r/r)، وبهذه الطريقة "يتحقق للبنية الفنية منطلقها العفوي للانتقال من مقطع الافتتاح إلى مقطع الرحلة إذ يغدو اليأس من بعض الماضي حافز

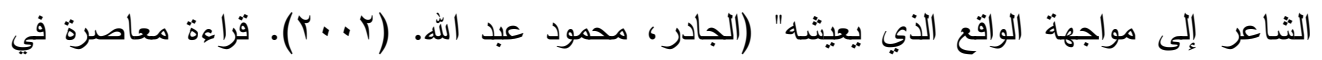
نصوص من التراث الشعري: •ع). و "لا شيء يثفي من الحب والهم سوى الرحيل ولا شيء يعزي سوى الرحيل أيضا" (رومية، د. وهب.

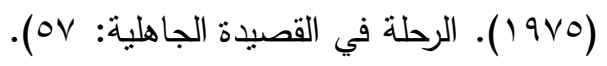


العدد الثاني والأربعون

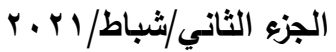

\section{جامسعة واسـط}

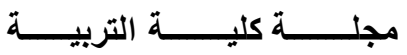

تشير لوحة الرحلة في القصيدة الجاهلية الى وجود صنفين من الرحلة:

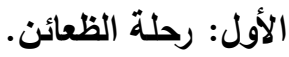

يقصد الثاعر برحلة الظعائن المشهد الأخير قبل مغادرة أحبته أو في أثناء مغادرتهم، فيعكس والبه

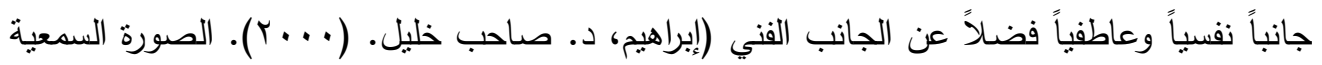
في الثعر العربي قبل الاسلام: 997). ، وغالباً ما يكون هذا المشهد قصيراً، لأنَّ مثل هكذا حثث يكون سريعاً ولاسيما إذا كان الرحالة

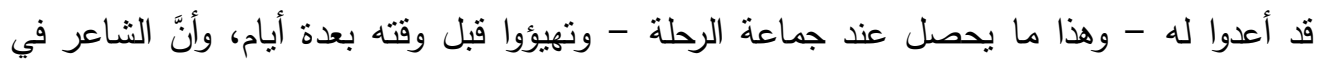

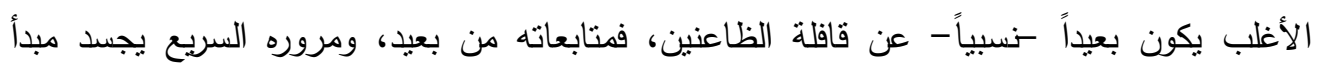
الأمانة في النقل، ومحاولة واقعية في تصوير الحدث، وفيه تعظيم للألم الذي عايثه الثاعر أثناء

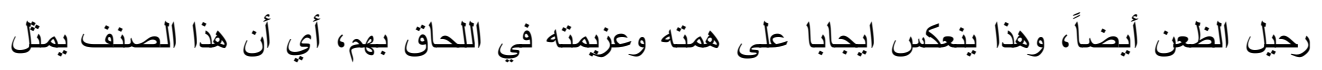
مقدمة للصنف الثاني.

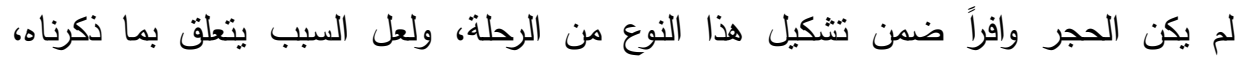

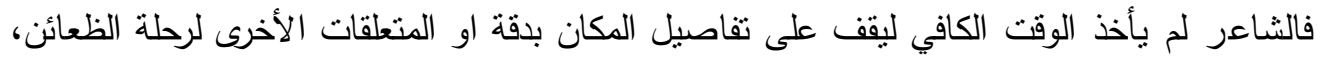

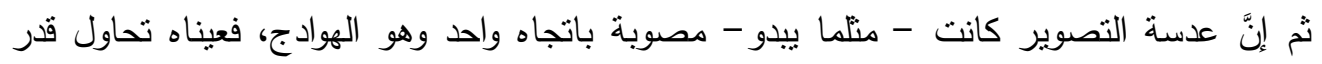
المسنطاع تحصيل صورة للمحبوبة فلا تكترث لما تقع عليه، وهناك سبب آخر ينطلق بطبيعة الرحلة

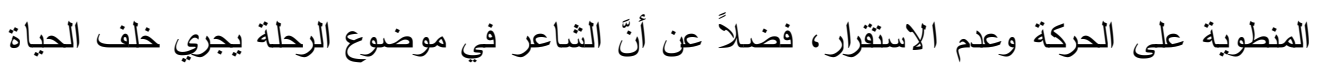

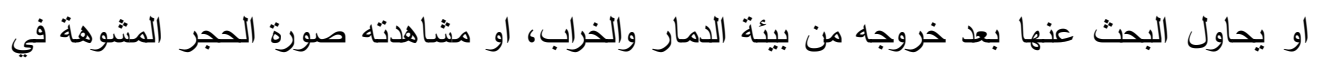

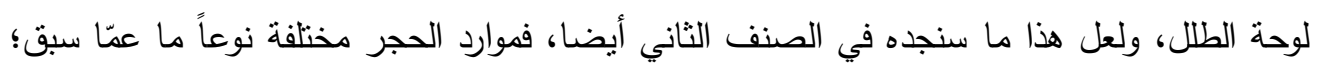

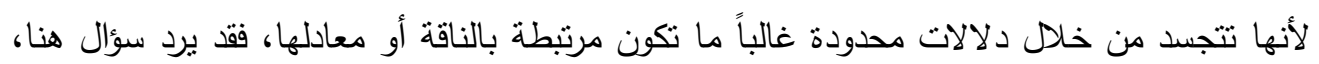
لماذا لا يصف الثاعر جِمال الظعائن منلما يصف ناقته؟

الثناعر في مقام الظعائن ربما يتجاوز وصف جِمالهم؛ لأنَّهَ يحاول أن بعطي فاصلا زمانياً بين

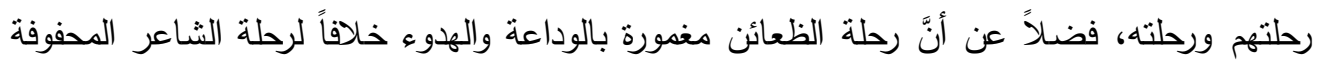

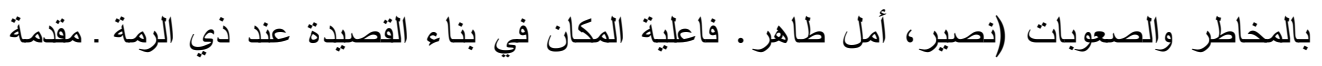

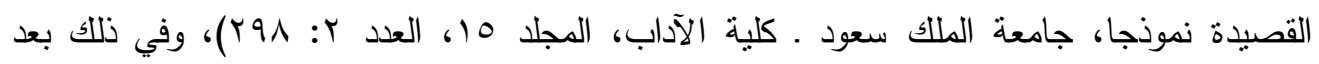

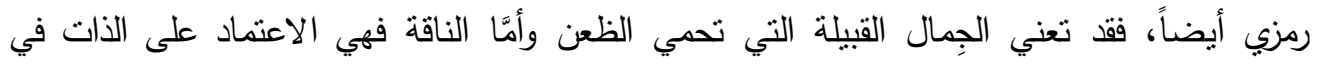

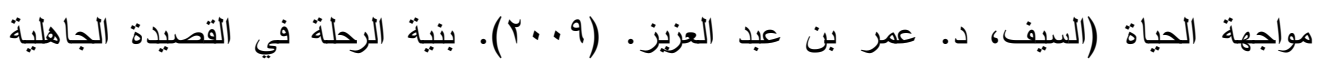

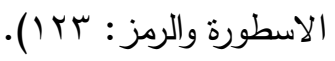


العدد الثاني والأربعون

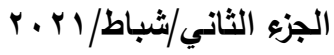

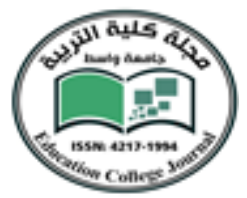

يقول امرؤ القيس (إبراهيم، محمد أبو الفضل. ديوان امرئ القيس: بعــء):

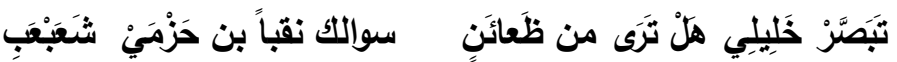

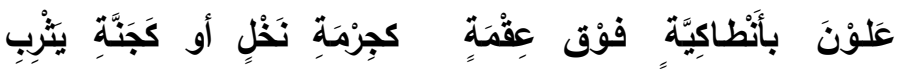

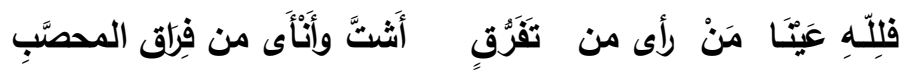

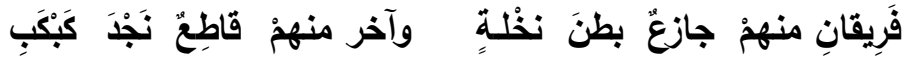

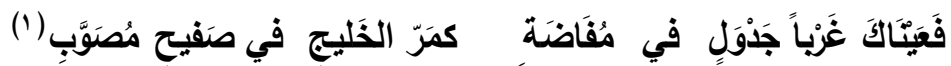

يبدو أنّ المسافة الزمنية التي تفصل بين امرئ القيس والظعن ليست قصيرة، لهذا كان طلبه مشوباً باليأس، وسؤاله يغمره الفقان وضياع الأثر، فقد كان هناك فاصلاً مكانياً وهو النقب، وهذا مرتبط بالزمن أيضاً، أي أنَّهم صاروا بذللك المكان لمرور زمن ليس بالقصير على رحيلهم، فضلاً عن كون النقب كان عاملاً أساسياً في حجب الرؤية عند الشاعر، على الرغم من أنَّهم كانوا لابسين ملابس مميزة ذات ألوان ظاهرة على بعد، وشبهـم بالبسر لكونه مميزاً وسط خضرة النخيل، وكذلك الحال بالنسبة الى بساتين يثرب، التي مما يميز تلك المدينة ويبدو فيها بوضوح لكثرته، لهذا كان الألم كبيراً جداً على امرئ القيس، وهو يتصور حاله معهم كرامي الجمرات في الحج، فما إن تتضضي تلك بكان الثعيرة حتى يغادر كل واحد منهم في صوب معين؛ فالفراق حاصل لا محال ونتيجة طبيعية لمثل حتل هذا الاجتماع، ولا شك أنَّ نلك مدعاة للحزن وباعثا للألم؛ لللك ترجمها بكثرة البكاء، وعبَّر عنها في تشبيه العينين بدلوين يصبان في أرض واسعة، إذ أراد أنَّ كثرة البكاء بطريقة تكون فيها العينان كالدلوين ستسنمر وقتاً طويلاً، فجعهما بصبان في أرض واسعة، ولعدم التوازن في طرفي الصورة

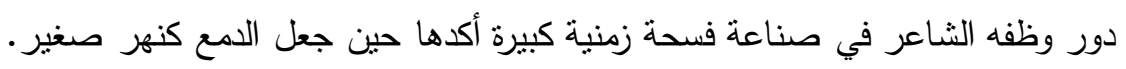
لقد ورد ذكر الحجر في هذا المقام في أربعة مواضع، وكانت له دلالات مختلفة، منها أنَّه كان

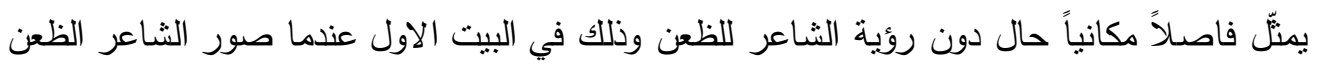
في النقب، وهو الطريق في الجبل، وهذا الحضور المكاني زحف على عامل الزهن وأسهم بشكل واضح في صناعة فاصلة زمنية حالت بين الشاعر والظعن، وشكلت مساحة وقتية أثرت على رؤية الثاعر، ولعل الموضع الآخر في البيت الرابع، وهو الذي أخذ دوراً مشابهاً للموضع الأول، حيث كان للجبل دور في سعة المساحة الفاصلة بين الثاعر والظعن، التي تتعكس على الزمن الفاصل بينهما، وأمَّا الموضع الثالث فهو في البيت الثالث، حيث شكل الحجر نقطة التقى عندها الجماعة، وذلك عندما صور الشاعر شدة الألم الذي يشعر به الحجاج حين يفترقون بعد اجنماعهم على رمي الجمرات، أي أنَّ في الحجر شيئًا مشتركاً يلتقي فيه الناس، ويتحابون من أجل ذلك اللقاء، وأمَّا 
العدد الثاني والأربعون

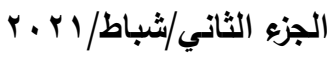

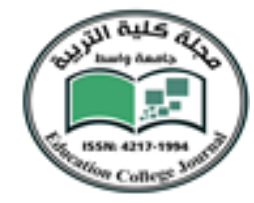

الموضع الرابع فهو في البيت الأخير حين أخذ الحجر دلالة الحفظ والاستمرار، إذ كان له دور اساسي في حفظ جربان الماء وتصويبه بالاتجاه الصحيح، وربما تلتقي هذه بالدلالة السابقة، إذ يمتّك الحجر فيهما دلالة الاجتماع والاستمرار، أي أنَّ الأرض هي العامل الرئيس في لقاء الناس واجتماعهم فهي المشترك الذي تحابوا فيه ومن أجله.

ففي الوقت الذي يكون الحجر فيه فاصلا بين الشاعر والظعن، يشكّل نافذة يطل من خلالها الانسان على حياة جديدة.

يقول زهير بن أبي سلمى (تعلب، أبو العباس احمد بن يحيى بن زيد الشيباني. (r97 ( ). شرح ديوان زهير بن ابي سلمى:

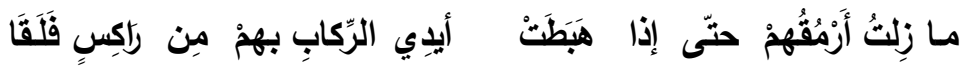

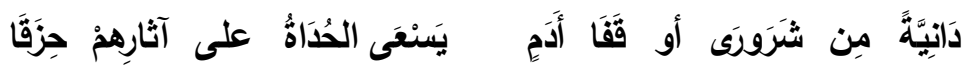

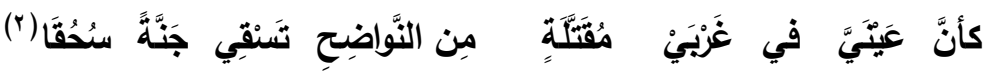
إنّ مدى الرؤية عند زهير نافذ الى مسافة جيدة وإلى ذلك يوحي التعبير، فـ(ما زلت) فيها دلالة على التواصل والاستمرار، ولكن حين يتخخل الحجر المتجسد بالجبل تتقع هذه الرؤية، فيصبح

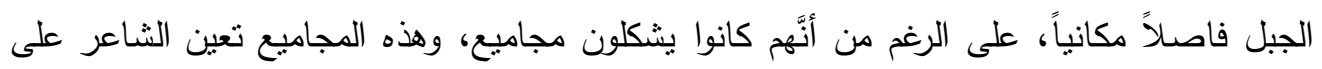
النظر والاستدلال، أبي أنَّها نكسر حاجز البعد الذي يفضل بين الشاعر والظعن. فالحجر يشكل فاصلاً بين الحياة الماضية القائمة على التراسل والقرابة، والحياة المتسترة بحواجز البعد والفراق، ثم إنَّه يمثّل نقطة النهاية التي يتجسد من طربقها الاستقرار والطمأنينة. الثاني: رحلة الشاعر.

ويُقصد بها مسيرة الثاعر التي يقطعها للحاق بالأحبة، أو إلى الممدوح، فقد تكون رحلة حقيقية

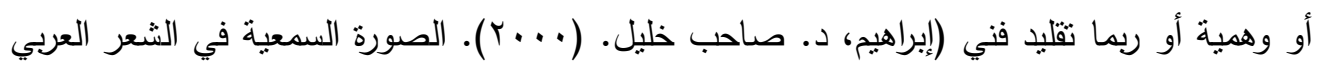
قبل الاسلام: 97)، ويطلق عليها صورة الناقة أيضاً (السيف، د. عمر بن عبد العزيز • (9. . (؟). بنية الرحلة في القصيدة الجاهلية الاسطورة والرمز: بال()؛ لأنّ الشاعر في هذا الصنف من الرحلة يكرس جهده في وصف الناقة، أو ما كان معادلا لها، أو أي حيوان يمكن أن يكون الثاعر قد شاهده في أثناء رحلته، تلك الحيوانات التي تمثل "أسطورة وظفت في الثعر لغايات فنية ودينية" (السيف، د. عمر بن عبد العزيز. (9 . . r). بنية الرحلة في القصيدة الجاهلية الاسطورة والرمز: 1 (1)؛؛ لهذا سيكون تركيزنا على دور الحجر في وصف الناقة وما شكّل معادلا لها. 
العدد الثاني والأريعون

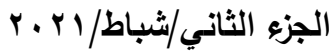

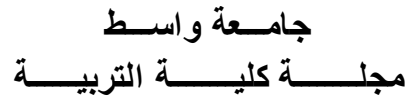

1 - الناقة.

استحوذت الناقة على وجدان الشاعر الجاهلي، إذ لم يلق حيوان اهنماماً لدى العرب - اذا ما استثنينا الفرس - منلما لقيت الناقة (حسين، د. محمد محمد. (9VY) ( I ). أساليب الصناعة في شعر

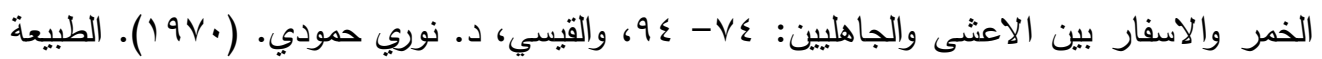
في الشعر الجاهلي، في مواضع متعددة، والجادر، د. محمود عبد الله. (9191). شعر أوس بن

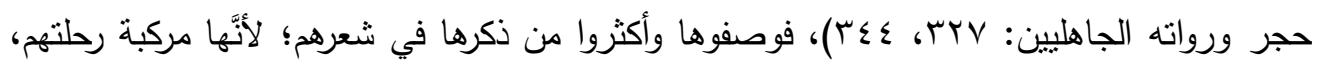
ومطية أهلهم، وأنيسهم في الصحراء، وهي غذاؤهم وطعامهم ولباسهم، وربما كانت نمنل الأمومة القوية منلما يرى ذلك الدكتور مصطفى ناصف (ناصف، د. مصطفى. (1919). قراءة ثانية لشعرنا القديم: . 1)؛ وترمز الناقة في الشعر الجاهلي إلى الصراع من أجل الحياة، بل هي التعبير الحقيقي عن استمراريتها (الشوري، مصطفى عبد الشافي. (71911). الشعر الجاهلي تقسير اسطوري: ( • ()؛ وهي أيضا وسيلة انطلاق الشعراء وسبيل إلى تحقيق وجودهم؛ ثم إنَّها وسيلة للتسلية ونسيان الهموم. لقد شكلت بعض أشكال الحجر معادلا للناقة من شدة التصاقه بها، حتى أصبحت هذه الاشكال جزءا من أسمائها، ويأتي في مقدة هذه الأشكال لفظة (عِرمِس)، التي تعني الناقة الصلبة الثديدة

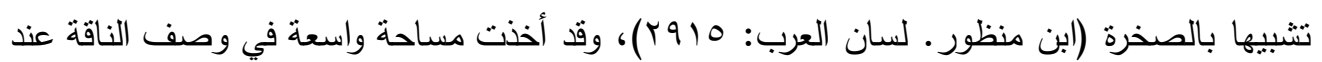
أغلب الثعراء الجاهلبين (r). يقول النابغة الذبياني (إبراهيم، محمد أبو الفضل. ديوان النابغة الذبياني: 10 (1)):

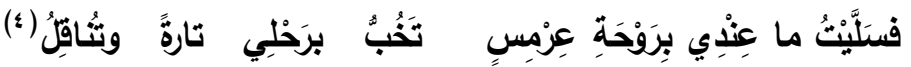
إنَّ الثاعر يصف ناقته بالشدة والصلابة والسرعة عندما حاول الخروج من أزمته النفسية

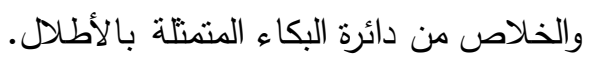

يبدو أنَّ الشاعر اختار بعض الصفات التي تعزز من ناقته، أو تبين آصرة النسب المرتبطة بالأصالة العربية، فقد عبَّر من طريق صفاتها عن بعض الدلالات التي ترتبط به أحيانا، فالثدة والصلابة تتعلق بعزيمة الثاعر على الرحيل؛ لأنَّه مقبل على صراع شديد تمثل البيئة الصحراوية الطرف الثاني فيه، التي خرجت منتصرة في صراع الطلل بعد أن سلبت منه معالم الحياة، وأبعدت عنه أحبته؛ لذلك احتاج إلى ناقة تمتلك المقدرة على تجاوز تلك البيئة القاسية المحفوفة بالمخاطر ، ثم حاول أن يركزّ على الجانب الموازي للصلابة، فوحدها لا تكفي، وإنما يحتاج إلى ناقة سريعة، تقصر له زمن الفراق، وتتجاوز تلك المخاطر بأقصى سرعتها. فشكل الحجر هنا يمنل واحد من الرموز للناقة، استعاره الثاعر ليكون ندا لنلك البيئة، التي 
العدد الثاني والأربعون

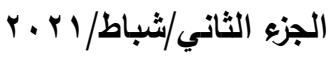

\section{جامسعة واسـط كليط}

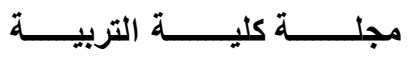

اعتاد في صراعه معها فيما سبق الرحلة أن يخرج الطرف المنهزم والخاسر، فحاول تجسيد تجربة

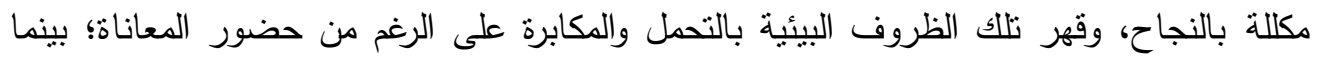
كانت السرعة تمثلّ نداً للزمن.

ومن اشكال الحجر التي كانت رمزا للناقة أيضاً (عَنْ)، وتعني الناقة القوية تثبيها بالصذرة

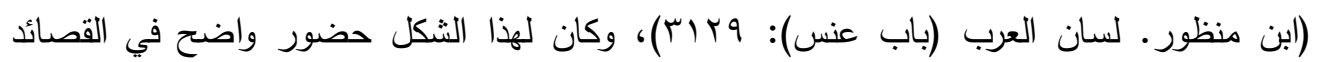

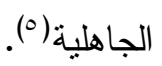

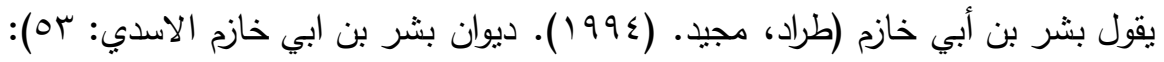

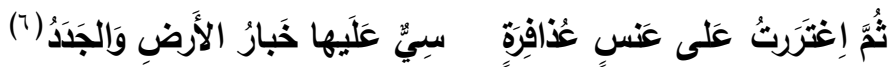

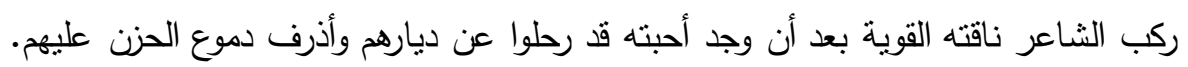

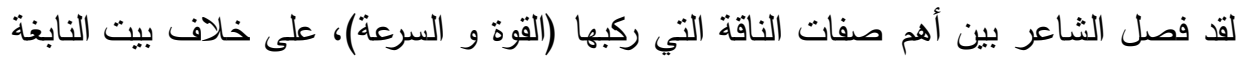

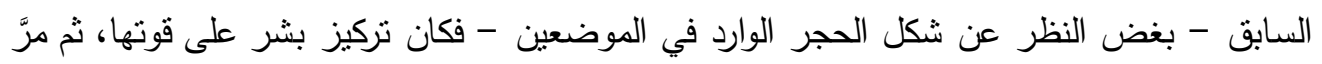

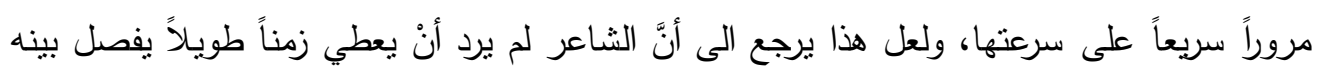

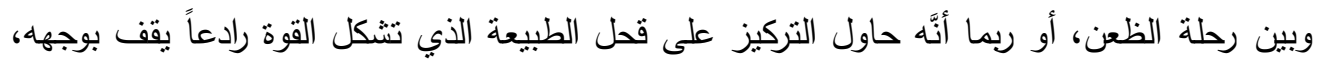

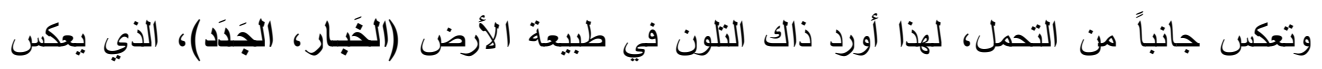

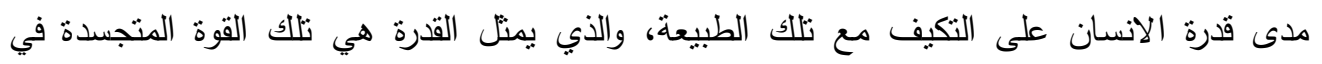

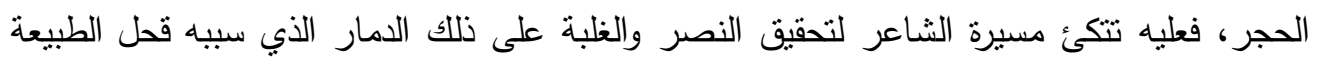

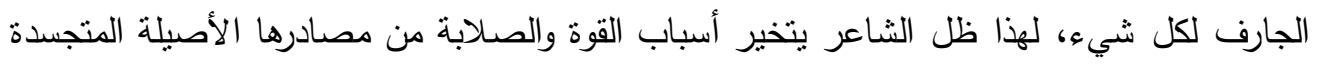

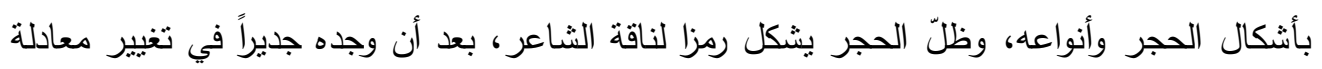

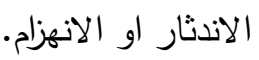

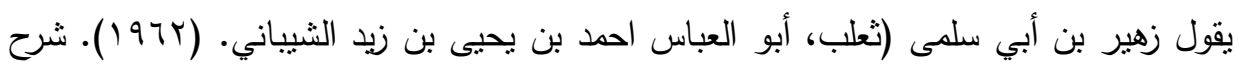

$$
\text { ديوان زهير بن أبي سلمى: • ب r): }
$$

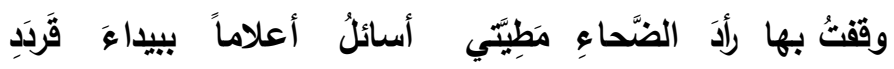

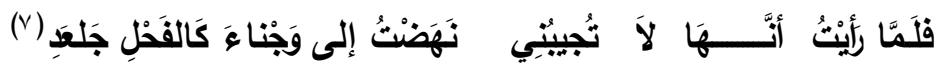

بعد أن يأس زهير من آثار الديار في أنَّها لا تجيبه قرر الرحيل ولحاق أحبته على ناقة صلبة

شديدة تتتاسب وطبيعة الصحراء التي سيجوبها.

يبدو أنَّ بعض وأثكال الحجر مختلفة في أسمائها، ولكنها نتيّل مرادفا للبعض الآخر، ولفظة

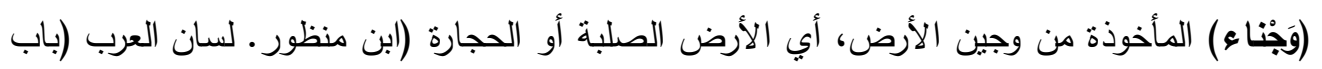


العدد الثاني والأريعون

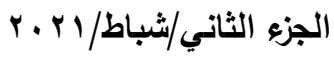

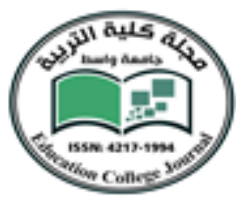

وجن): \&VV\&)، الني نعني الناقة الصلبة الثديدة، ولها نصيب من الحضور (^)، هي مرادفة لصفة الناقة (عِرْمِس).

يبدو أنَّ الشاعر جاء بصفة الناقة هذه؛ لأنه شاهد قبل قليل اندثار كل ما في الديار إلا بقايا مشوهة تدل عليها تلك الأرض الصلبة (قَرْدَد)، فأخذ من هذه الأرض صفة الصهاء الصلابة والثدة ليستعين بها على تجاوز محنة الصحراء المهلكة؛ لهذا اختار صفات مساندة لتلك الصفة، فالفحل هو الجمل الذي لا يركب ولا يستعمل وإنَّما يترك للفحولة فقط، أبي أنَّه قصد النشاط والحيوية التي تمد ثلك هون الصلابة والثدة بالاستعداد.

ومن أشكال الحجر التي شكلت رمزا للناقة أيضاً (حَرْف)، أي قطعة من جبل، ويراد منه الصلابة والثدة أيضاً (9).

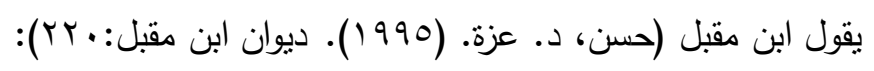

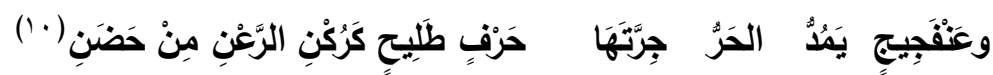

ناقة ابن مقبل صلبة شديدة عظيمة عظم الجبل رغم كبر سنها، وأثز السفر البالغ فيها. لقد ظلَّ الجبل مضرباً للمنل في الديمومة والصمود على الرغم من تعاقب السنين عليه، وعلى الرغم من حجم التغيرات ونوعها التي أحدثها الزمن في البيئة؛ لذا حرص الشعراء على أن يكون لهذه القابلية حضور في نوقهم، ولاسيما إذا كانوا يصورون قسوة السفر ومشاق الطريق، خصوصا اذا أحسَّ الثاعر أنَّه وحيد وسط تلك الصحراء المترامية الأطراف، وأنَّه في سباق مع الزمن، فاتخذ من الجبل نصيرا له، أي أنَّ الجبل يمنل طرفا تجسد في الناقة مع تلك البيئة القاسية المتمثلة بالصحراء في معادلة الحياة، ولعل هذا يجري مع كل أشكال الحجر التي شكلت معادلا للناقة. إنَّ للحجر حضوراً واضحاً في صور الثعراء التي وصفوا بها نوقهم، فقد لا نجد عضواً من وند أعضائها إلا وكان الحجر متجسداً فيه بأثكال وأنواع مختلفة، إذ كان يمثل دلالة القوة والثدة والصلابة. r - بالثور الوحشي.

حين نتبع صورة الثور الوحشي في الثُعر الجاهلي نلاحظ أنَّ الصورة الممثدة بدلالاتها الأسطورية جاءت لتعبر عن قوة ومنانة ناقة الشاعر ، فيمثل شبيه راحله، لهذا نرى الشعراء الجاهليين "قد جعلوا الصائد يخفق كل مرة في قنصه، وهم يفعلون ذلك ليققوا شبيه راحلتهم عزيزاً قوياً" (أمين، عبد القادر حسن. (9VYY). شعر الطرد عند العرب: (YM)، ثم إنَّهم يعكسون من طريقه صورة الحياة والكفاح من أجلها؛ والثور مقد عند القدماء كونه يرمز إلى القوة والخصب(' (')، ولكن وهب 
العدد الثاني والأربعون

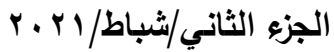

\section{جامسعة واسـط كلئ}

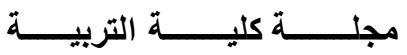

رومية يقول: "لقد شاءت الأقدار وحظه السيئ أن يكون في موطن الثر والمخافة وأن تكون فرص الاختيار أمامه ضيقة وقليلة ويفزع الثور عادة للخروج مما هو فيه إلى إحدى السبيلين - وكلتاهما

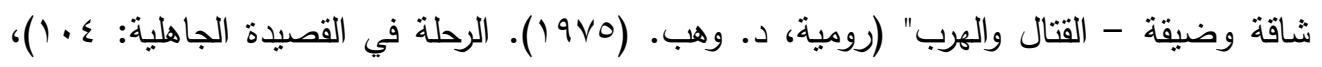

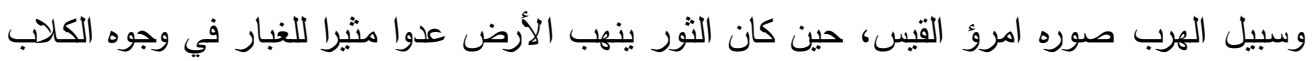

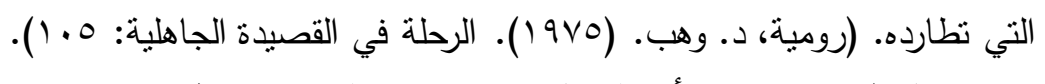

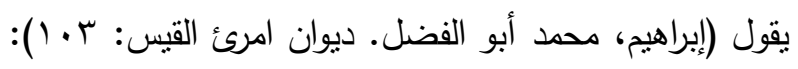

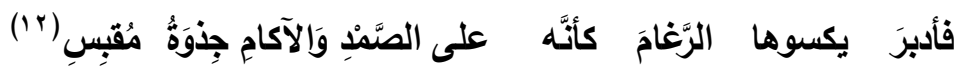
إنَّ امرأ القيس بصف حال ثور الوحش حين أحس بالكلام، فكان مسرعاً قوياً بثير خلفه الغبار

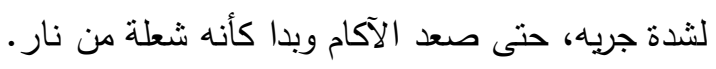

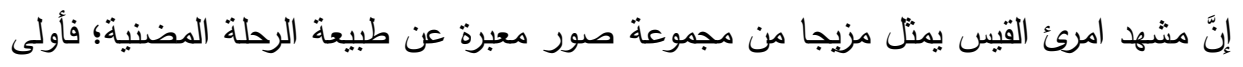

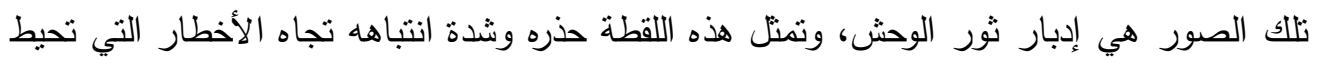

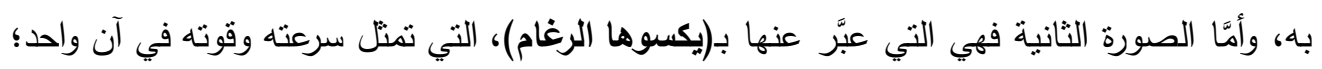

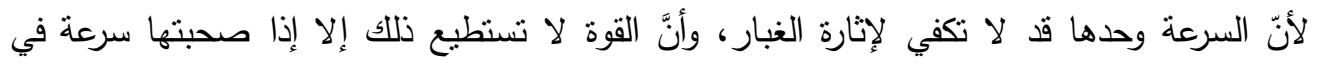

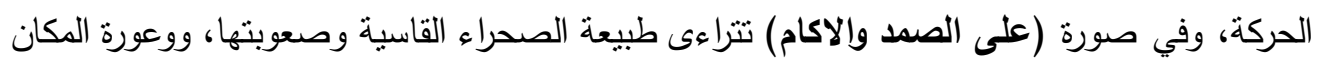

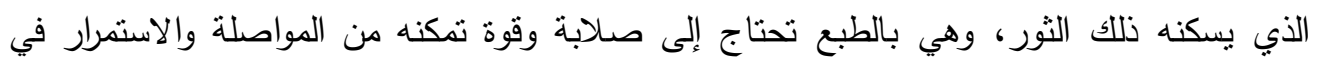

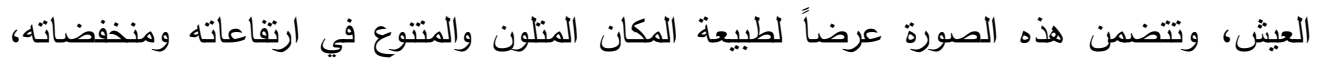

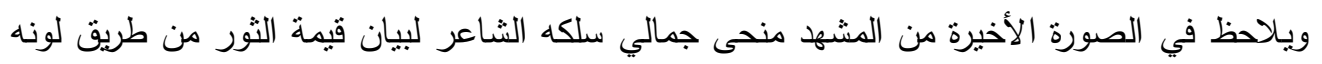

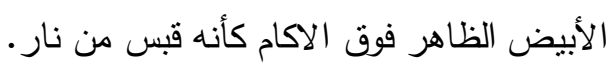
وقد يصف الشاعر ثور الوحش فيضفي عليه صفات القوة والصلابة والسرعة، ويقيم بين الثور والناقة علاقة من النشابه والنقارب.

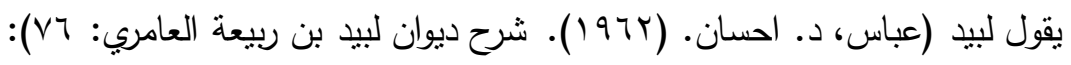

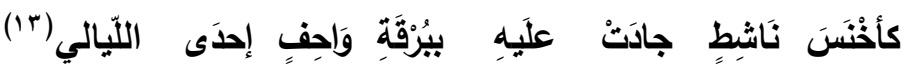

يشبّّه لبيد ناقته بثور الوحش الأخنس النشيط عندما كان في لبلة من الليالي ببرقة واحف تحت المطر. وهذا مشهد آخر يتضمن العديد من الصور التي سجلتها عدسة خياله، عندما كان يقطع الصحراء،

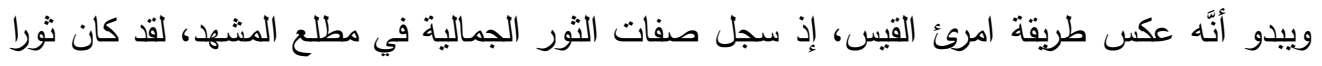

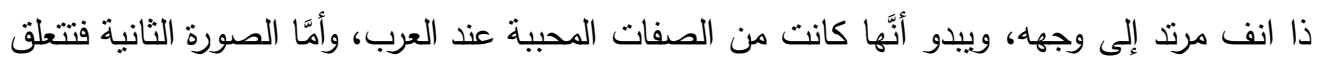


العدد الثاني والأربعون

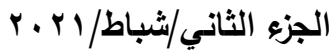

\section{جامسعة واسـط كليط}

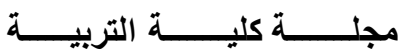

بسرعة الثور وخفته؛ لأنَّهَ بمنلك المقدرة على المداولة من مكان إلى آخر بسرعة، ثُ كانت الصورة

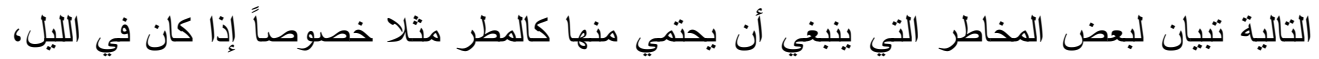

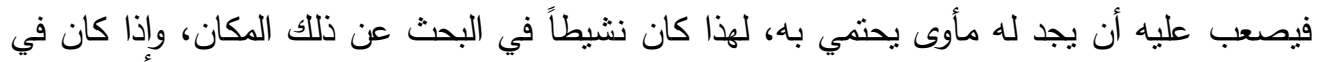

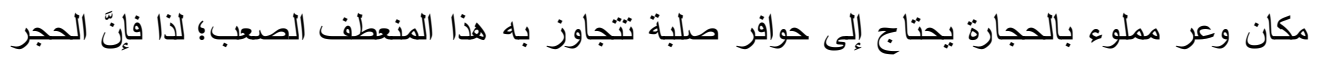

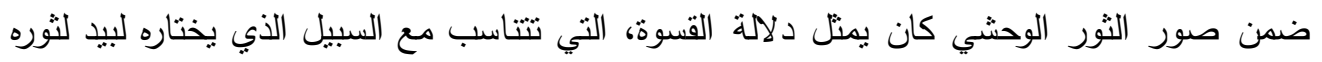

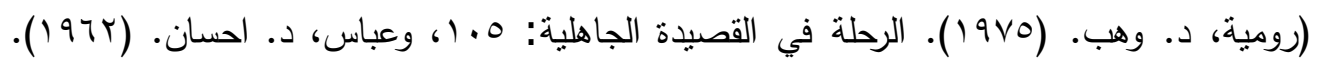

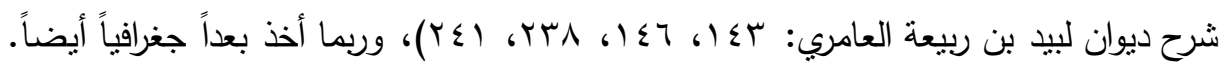

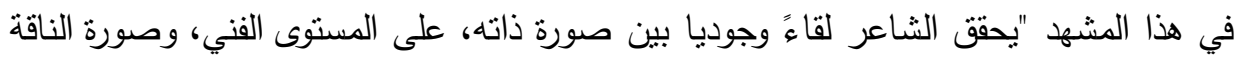

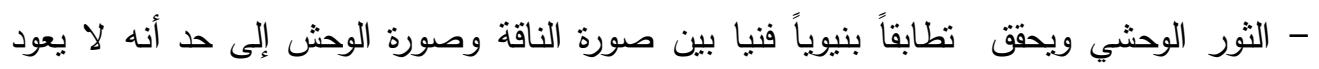

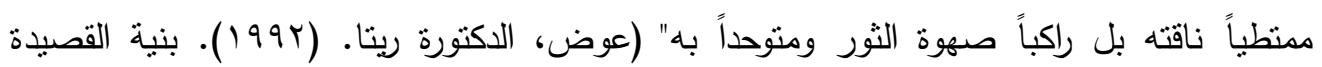

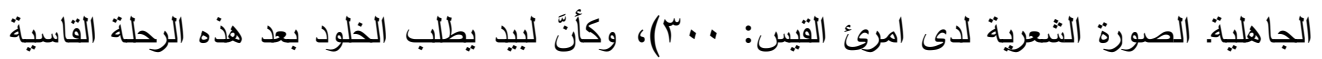

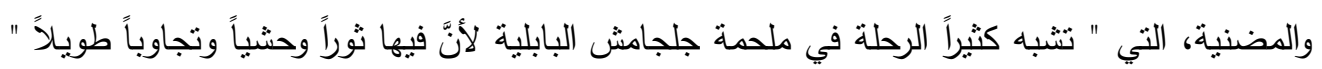

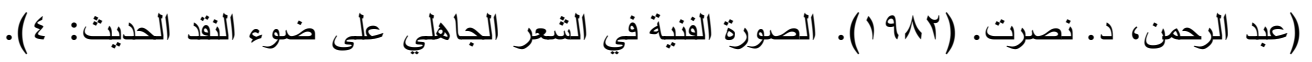

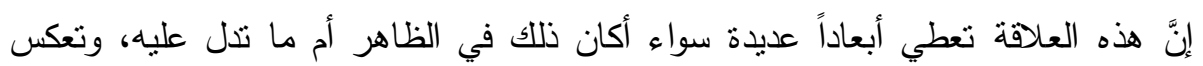

روية دقيقة للحياة والإنسان في نلأك المرحلة.

ب - حمار الوحش.

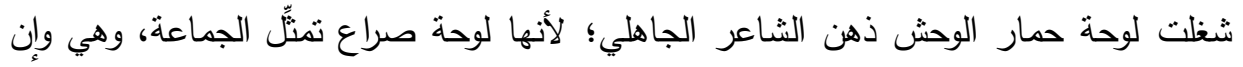

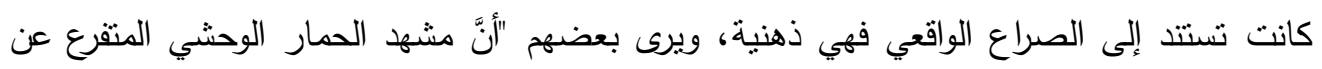

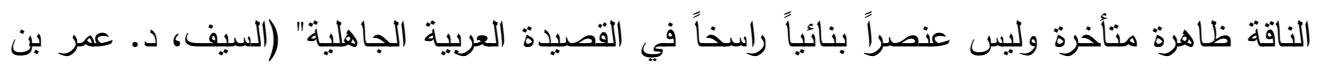

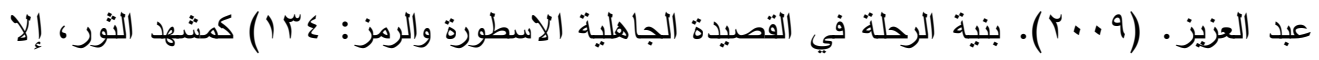

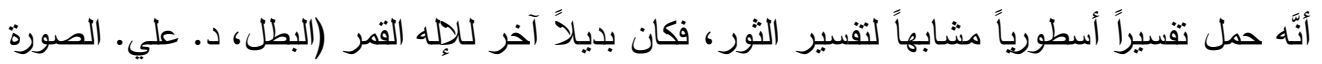

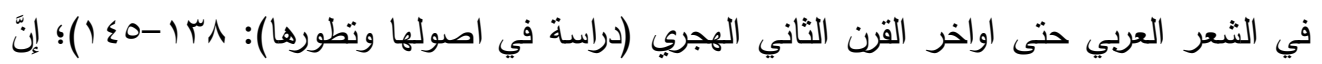

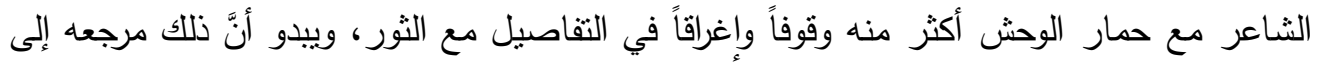

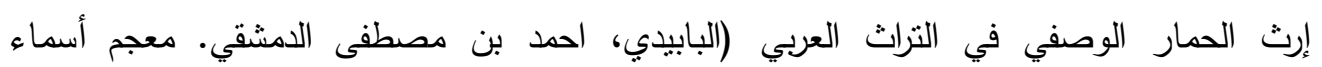

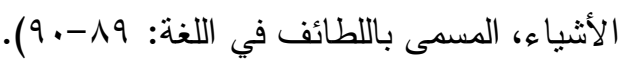
يقول زهير بن أبي سلمى (ثعلب، أبو العباس احمد بن يحيى بن زيد الشيباني. (1971). شرح ديوان

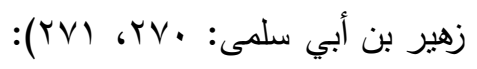


العدد الثاني والأربعون

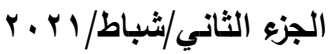

\section{جامسعة واسـط كلئ}

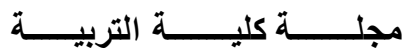

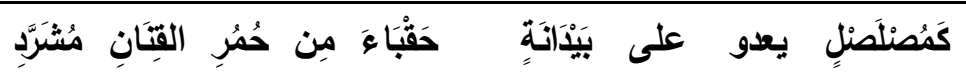

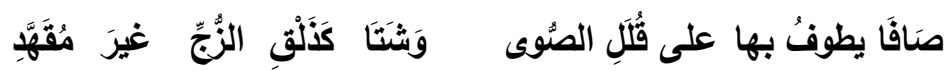

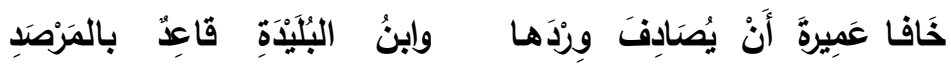

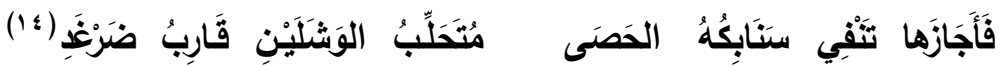

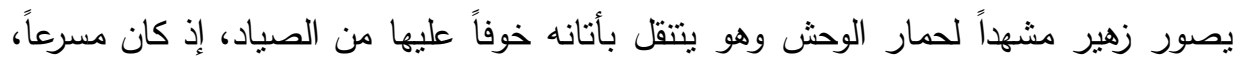
يضرب حصى الحوافر أنفه من شدة السرعة، محاولة منه لإنقاذها والوصول بها إلى عين الماء.

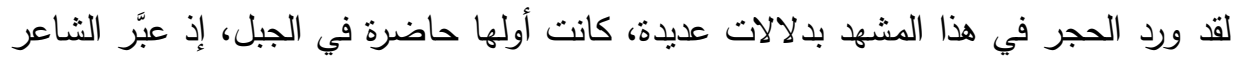

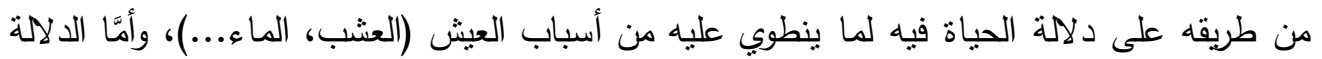
الثانية فقد تضمنتها (الصُوى)، التي أخذت ثلاثة أبعاد: الأول جغرافي، صور من طريقه الثاعر

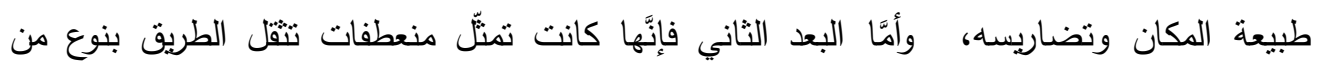

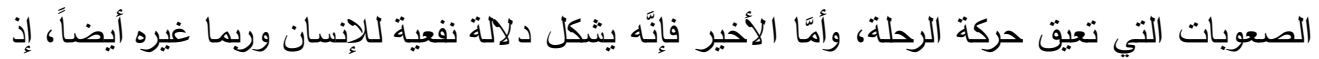

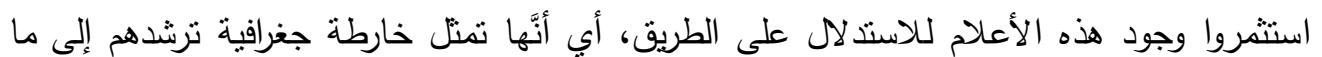
يقصدون؛ وأمّا الدلالة الثالثة فهي دلالة السرعة والخفة الحاضرة في الحصى، التي تشكل مفتاح الخلاص من ذلك الخطر المحدق بهما. وقد يعطي الثاعر الحمار الذكورة البشرية التي تتفجر غيرة، إذا أحسَّ أنَّ أحداً غيره اقترب من زوجه روهاً أو جسداً.

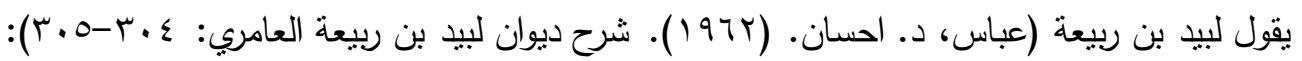

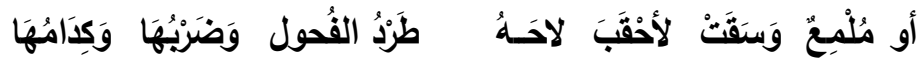

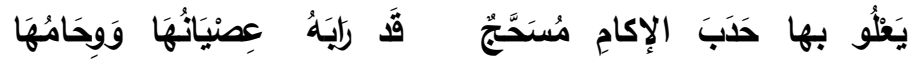

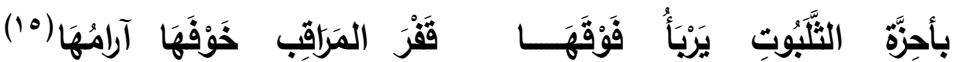
يحكي هذا المشهد قصة حمار الوحش وهو ينجو بأتانه الحامل من خطر الفحول الأخرى إلى الى

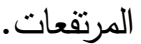
يشكّل الحجر هنا دلالة الأمن التي تجسّت في حضور الآكام، فالحمار قد لا يجد مكاناً أكثر

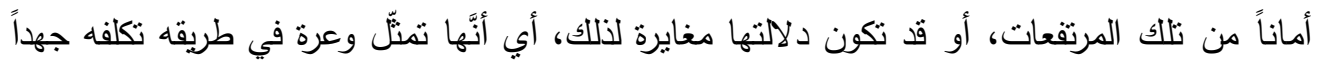

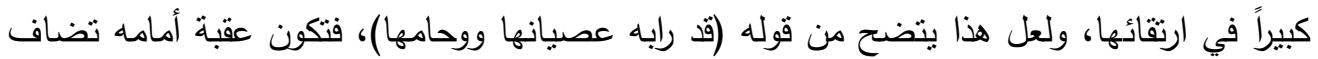

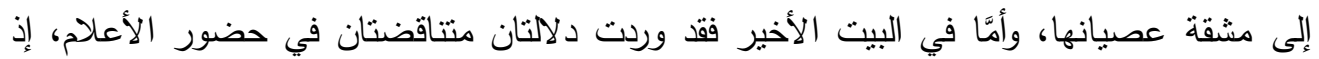
تشكل المراقب مرصداً يترقب الحمار منه محيطه والمخاطر التي تهدده، أب أنَّها تحمل دلالة العلو 
العدد الثاني والأربعون

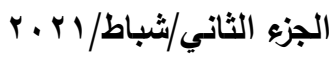

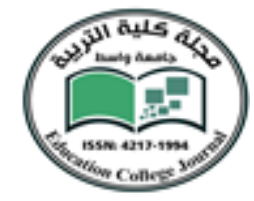

والارتفاع، كونها تشرف على ما دونها من سائر المرتفعات الأخرى.

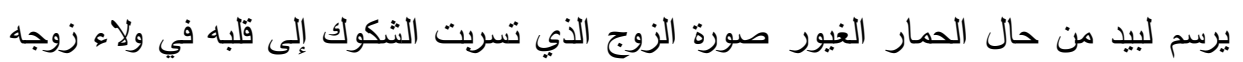
ولاسيّما أنَّه يعرف شهوتها الجامحة إليه فيتفاجأ بصدها وتمنعها فتغلو في نفسه الريبة فينشد بها البعد والوحدة (رومية، د. وهب. (9V0 ()). الرحلة في القصيدة الجاهلية: بسا))، اللذين تمثنا بالحجر.

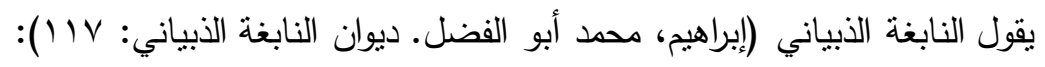

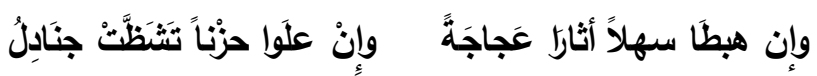

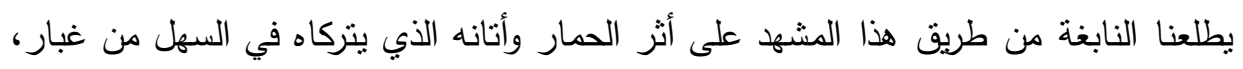
وتكسير الحجارة إذا علا أرضاً غليظة.

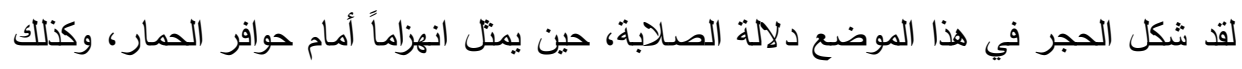
دلالة القوة التي تشنتف من التشظي، لذا كان اعتلاؤه الأرض الصلبة يمنل صلابة الحوافر، وأمَّا

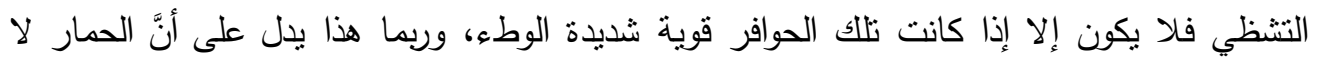
يعبأ إلى موطئه سواء أكان سهلا أم مرتفعاً غليظاً، والأخير يعني صعوبة في المراس أو عقبة في الطريق ضمن تلك البيئة.

\section{ع -الظليم والنعامة.}

اختلف مشهد الظليم والنعامة في الرحلة عن مشاهد الحيوانات الأخرى نوعا ما، فقد كان أقلّ ظهوراً في ساحة الرحلة، وأكثر غموضاً (البطل، د. علي. الصورة في الثعر العربي حتى اواخر القرن الثاني الهجري (دراسة في اصولها ونظورها): 0 ؛ ()، وربَّما يكون الثعر الجاهلي قد غيبّها قياساً بصور نظيربها (الثور والحمار)، فنفسه فيها كثهقة الموت التي سرعان ما تتقضي، ولعل هذا مرجعه، إلى قلة الأحداث والثخوص التي تجعل إبداع الشعراء رهناً بقدتهم على التصوير (رومية، د. وهب. (9V0 (19v). الرحلة في القصيدة الجاهلية:ror)؛ ويشكل الظليم شبيها للناقة في رحلتها مع إع قرينيه الثور والحمار .

يقول عنترة بن شداد (مولوي، محمد سعيد. (£ (97 )). ديوان عنترة: 99 (1)):

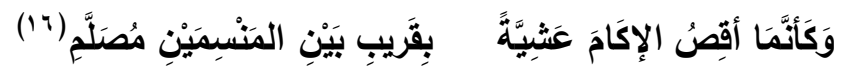

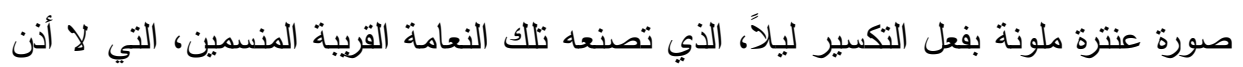

لقد أينعت صورة عنترة بدلالات الصلابة والقوة والعزم وركوب الصعاب، التي تضمنتها عبارة 
العدد الثاني والأربعون

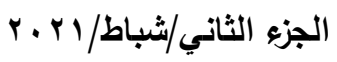

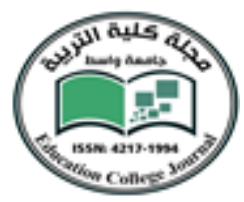

(أقصصُ الاكَامَ عَشِيَّةً) في صدر البيت، فالفعل أقصّ يتطلب صلابة وقوة كي يتحقق، والاكام تحتاج

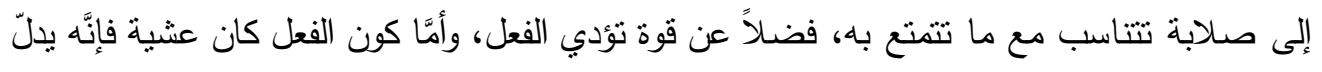

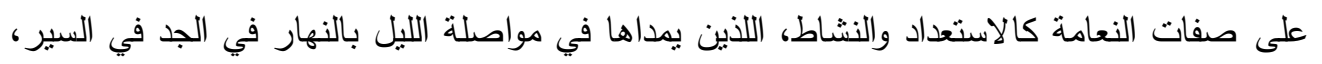

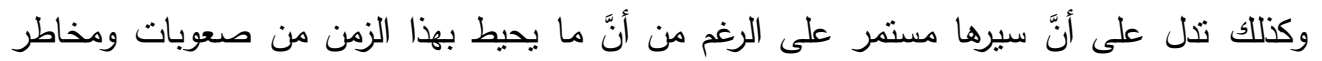
الطريق.

وقد يعالج الثاعر مشكلة الفناء الكبرى من طريق التجدد وأسباب الحياة التي يجسدها الظليم

والنعامة.

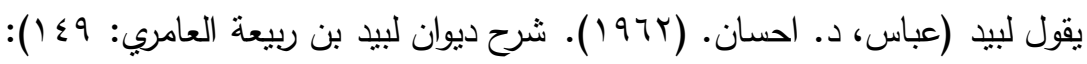

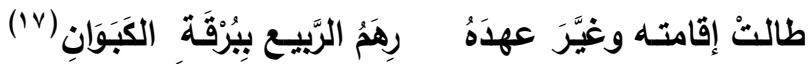

يقصد لبيد بهذا البيت أنَّ السبب في بقاء الظليم والنعامة ببرقة الكبوان هو الصورة الجديدة التي حلت بالمكان بسبب مطر الربيع الخفيف.

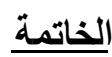

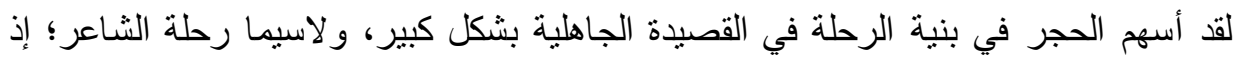

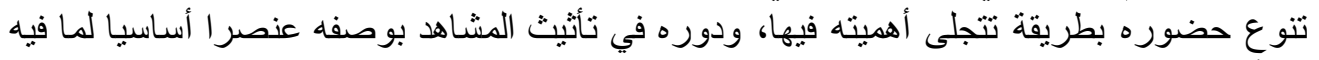
من أبعاد و اقعية ورمزية.

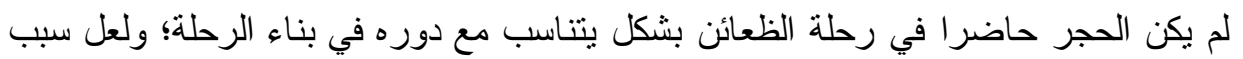

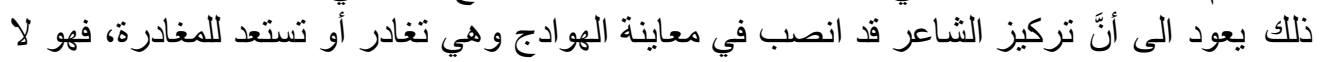

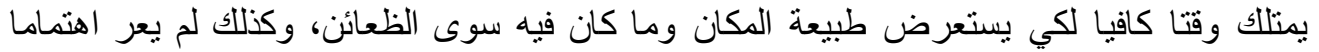
للجِمال التي حملت تلك الظعائن إلا قليلا.

إنَّ للحجر أثرا كبيرا في بناء رحلة الثاعر؛ فقد اتسع وجوده حتى شمل كل مفاصل هذا النمط

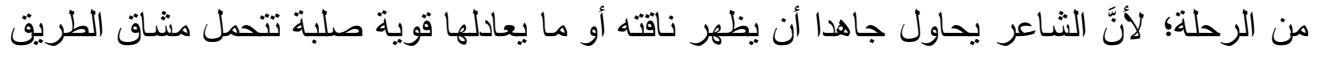

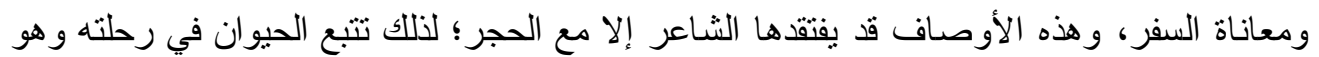
يضفي عليه كل صفات القوة و الصلابة من طريق نشبيهه بالحجر. 
العدد الثاني والأربعون

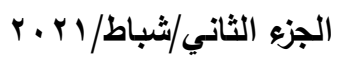

(') الظعائن: النساء في الهوادج، الحزم: ما غلظ من الارض، النقب: الطريق في الجبل، شعبع: اسم ماء، علون بانطاكية: أي علون الخدور بثناب عملت في انطاكية وقوله: كجرمة نخل: ما يصرم من البسر، الجنة: البناء البستان، قوضله:

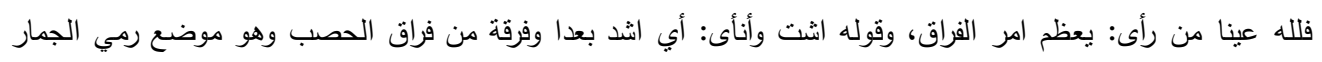

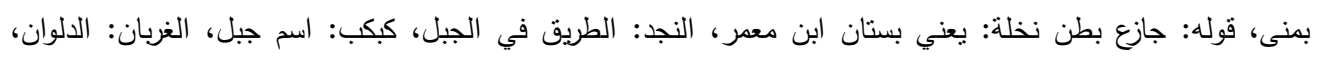

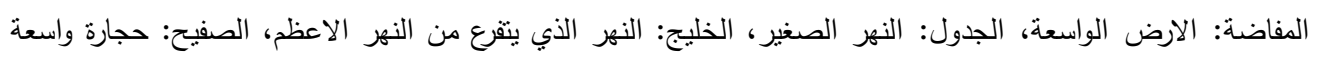

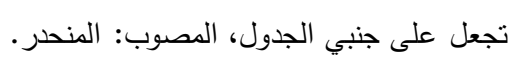

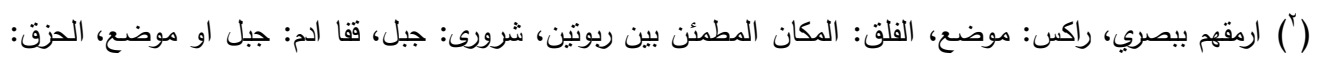

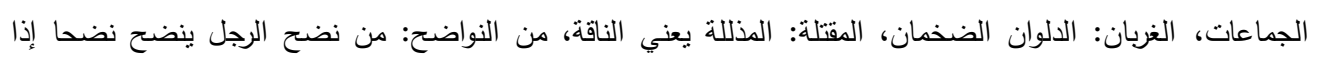

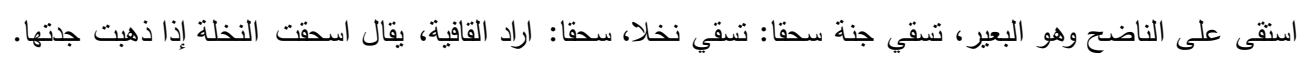

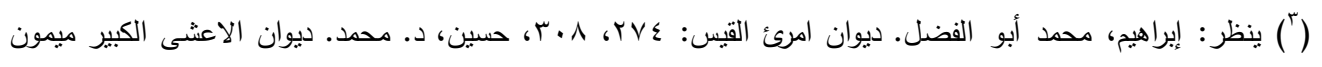

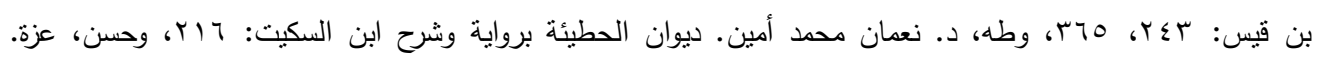

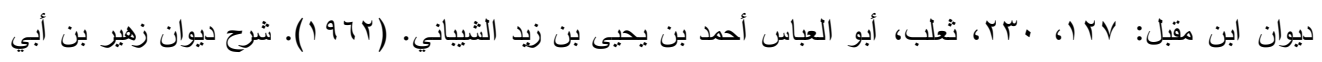

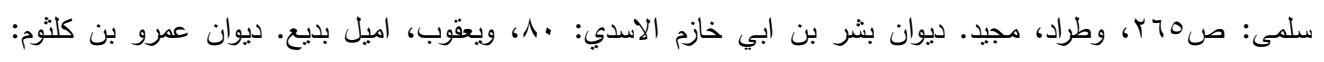

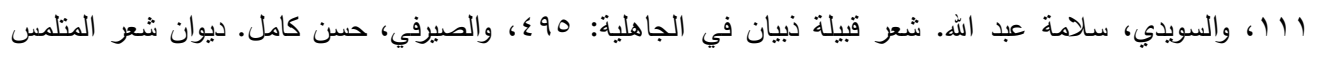

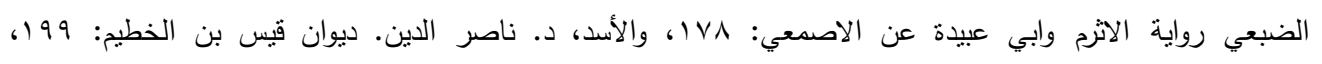

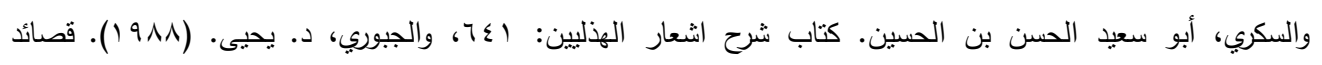

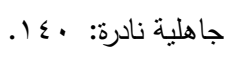

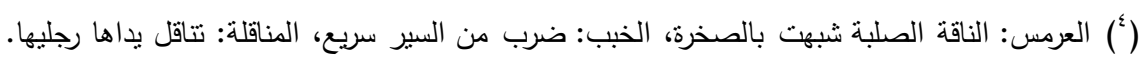

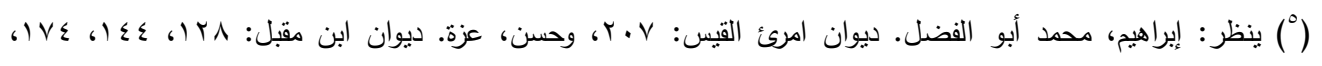

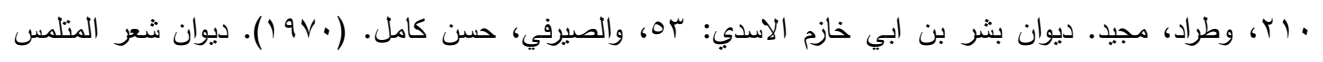

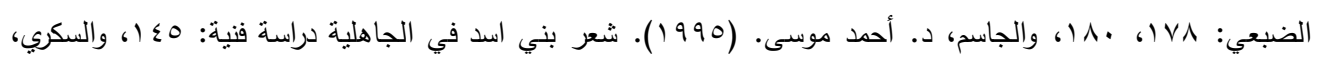

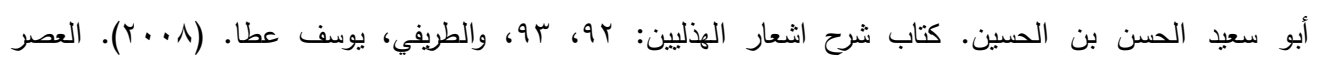

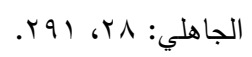

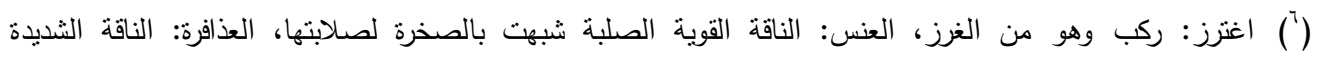

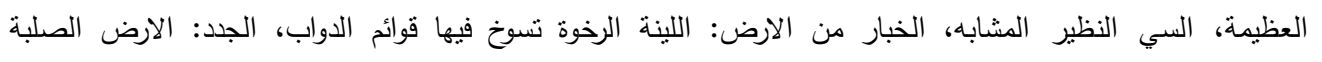

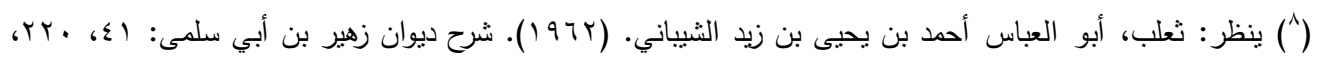

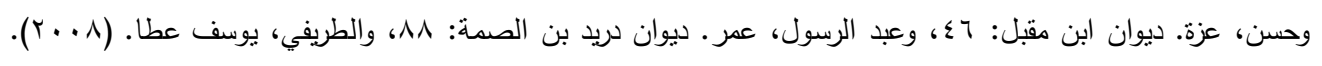

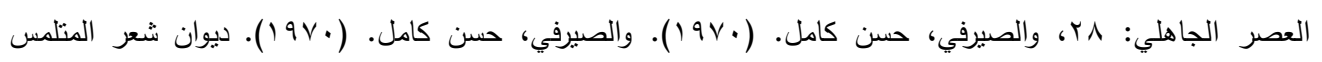


العدد الثاني والأربعون

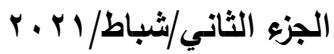

جامسعة واسـط

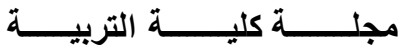

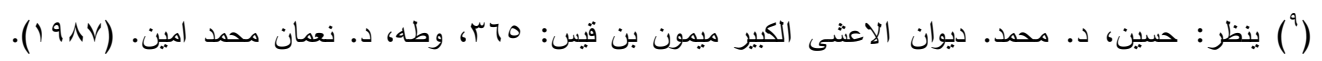

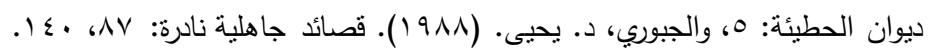

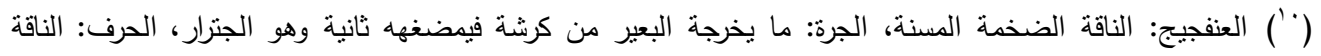

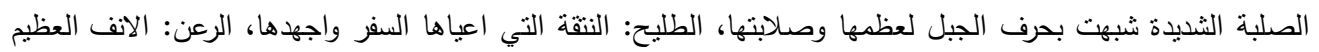

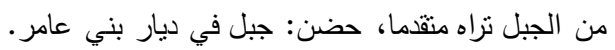

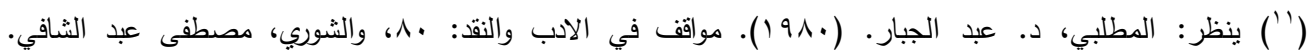

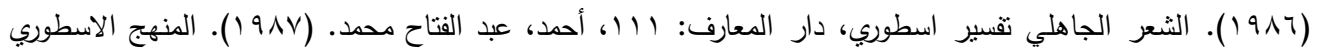

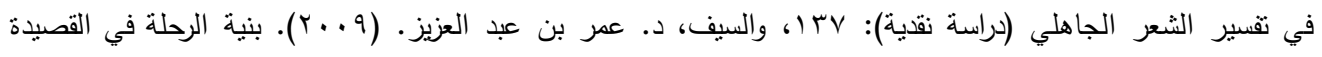

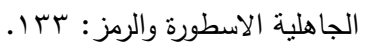
(r) قوله: فادبر يكسوها الرغام: أي رجع الثور عن وجهه الذي كان يقابله لما أحس بالكلاب، الرغام: التراب، الصمد:

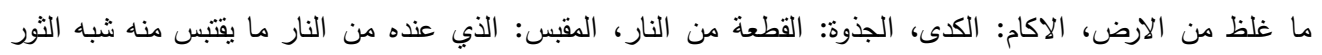

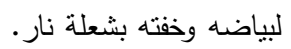
(rآ) الخنس: الثور، شبه الناقة به، ناشط: يخرج من بلد الى بلد، واحف: مكان، البرقة: الموضع يخلط نرابه او رمله حصى، خنس الثور: ارتداد انفه في وجهه. (") يعني كعير مصوت وهو المصلصل، بيدانة: انانا وحشية حقباء: في موضع الحقيبة منها بياض، القنان: جبل لبني

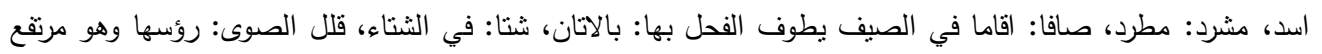
من الارض غليظ، ذلق: حد، مقهد: بادن سمين، يقال تقهر اذا سمن، عمبرة: صائد، وردها: ورد الاتان، ابن البليدة:

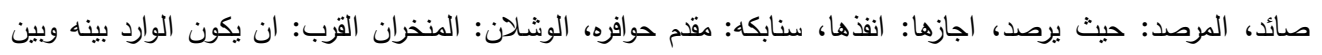

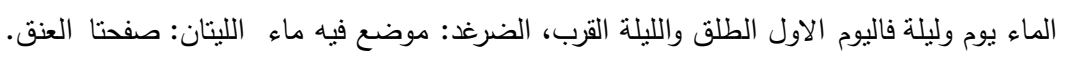

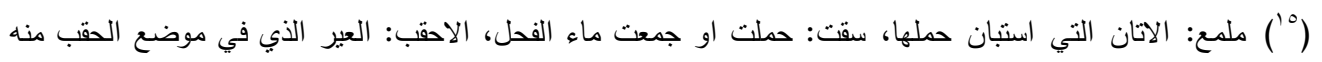

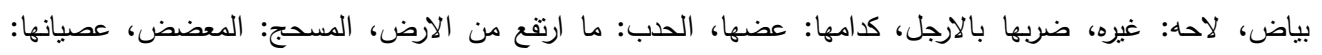

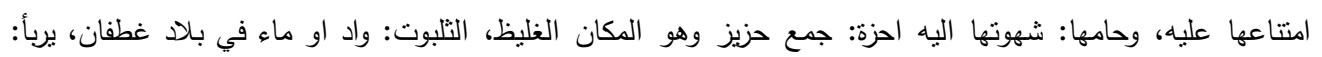
يقف طليعة ويشرف ويعلو، المراقب: المواضع المشرفة، الارام: اعلام الطريق.

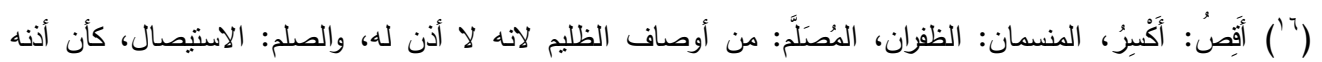


العدد الثاني والأربعون

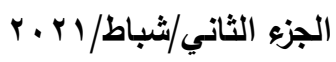

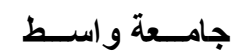

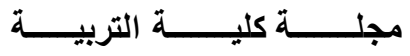

\section{مصادر البحث ومراجعه}

إبراهيم، د. صاحب خليل. ( . . ץ). الصورة السمعية في الثعر العربي قبل الاسلام . دراسة، منشورات اتحاد الكتاب

$$
\text { العرب . دمثق. }
$$

إبراهيم، محمد أبو الفضل. ديوان النابغة الذبياني، دار المعارف ـ القاهرة، الطبعة الثانية.

إبراهيم، محمد أبو الفضل. ديوان امرئ القيس، دار المعارف، القاهرة، الطبعة الرابعة.

ابن منظور. لسان العرب، ت: عبد الله علي الكبير ومحدد احمد حسب اله وهاشم محمد الشاذلي، دار المعارف .

القاهزة، (د.ط).

أحمد، عبد الفتاح محمد. (9Av (19). المنهج الاسطوري في تقسير الثعر الجاهلي (دراسة نقية)، دار المناهل للطباعة والنشر والتوزيع • بيروت لبنان، الطبعة الأولى.

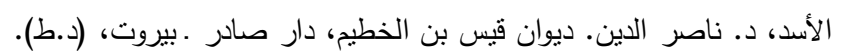

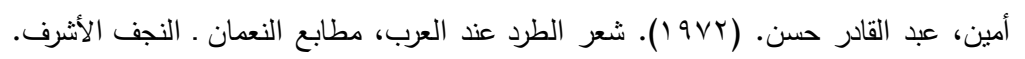

البابيدي، أحمد بن مصطفى الدمشقي. معجم أسماء الاشياء، المسمى باللطائف في اللغة، دراسة وتحقيق: احمد عبد

التواب عوض، دار الفضيلة للنشر والتوزيع والتصدير ـ القاهرة، (د.ط).

البطل، د. علي. الصورة في الثعر العربي حتى اواخر القرن الثاني الهجري (دراسة في اصولها وتطورها)، دار

الاندلس للطباعة والنشر والتوزيع، (د.ط).

ثُعلب، أبو العباس أحدد بن يحيى بن زيد الثيباني. (r (971). شرح ديوان زهير بن أبي سلىى، الهيئة العامة للكتاب،

الدار القومية للطباعة والنشر القاهرة ، (د.ط).

الجادر، د. محمود عبد الله. (.919). شعر أوس بن حجر ورواته الجاهليين، دار الرسالة للطباعة، بغداد.

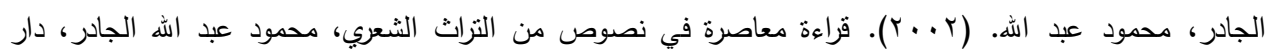

الثؤون الثقافية العامة، بغداد، الطبعة الأولى.

الجاسم، د. أحمد موسى. (1990). شعر بني اسد في الجاهلية دراسة فنبة، دار الكنوز الادبية ـ بيروت ـ لبنان،

$$
\text { الطبعة الأولى. }
$$

ه الجبوري، د. يحيى. (911 (1). قصائد جاهلية نادرة، مؤسسة الرسالة للطباعة والنشر والتوزيع ـ بيروت، الطبعة الثانية.

حسن، د. عزة. (990 1). ديوان ابن مقبل، دار الثرق العبي . بيروت . لبنان، (د.ط).

حسين، د. محمد. ديوان الاعشى الكبير ميمون بن قيس، المطبعة النموذجية، (د.ط).

هسين، محمد محمد. (Y (9VY). أساليب الصناعة في شعر الخمرة والاسفار بين الاعشى والجاهليين، دار النهضة العربية، بيروت، الطبعة الاولى. 
العدد الثاني والأربعون

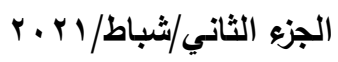

جامــعة واســ كلـ

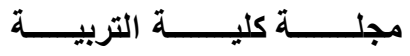

رومية، د. وهب. (9v0) (الرحلة في القصبدة الجاهلية، اتحاد الكتاب والصحفيين الفلسطينيين، الطبعة الأولى.

السكري، أبو سعيد الحسن بن الحسين. كتاب شرح اثعار الهذليين، ت: عبد الستار احمد فراج، راجعه محمود محمد

شاكر، مطبعة المدني، القاهرة، (د.ط).

السويدي، سلامة عبد الله. (9Av (19). شعر قبيلة ذبيان في الجاهلية، مطبوعات جامعة قطر، الطبعة الأولى.

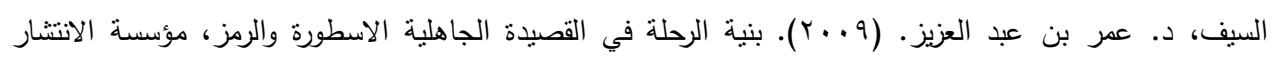

العربي • لبنان.

الثوري، مصطفى عبد الثافي. (1911). الثعر الجاهلي تقسير اسطوري، دار المعارف ـ القاهرة ـ مصر، الطبعة

الأولى.

الصيرفي، حسن كامل. (·9V) (1). ديوان شعر المتلمس الضبعي رواية الاثرم وابي عبيدة عن الاصمعي، معهد

المخطوطات العربية، (د.ط).

• طراد، مجيد. (ع (99). ديوان بشر بن ابي خازم الاسدي، دار الكتاب العربي • بيروت، الطبعة الأولى.

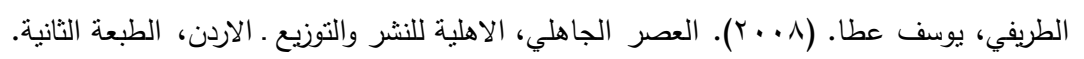

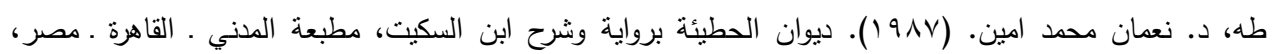

الطبعة الاولى.

• عباس، د. احسان. (r 97 (1). شرح ديوان لبيد بن ربيعة العامري، مطبعة حكومة الكويت ـ الكويت.

عبد الرحمن، د. نصرت. (به19). الصورة الفنبة في الشعر الجاهلي على ضوء النقاء الحديث، مكتبة الاقصى .

عمان ـ الاردن، الطبعة الثانية.

عبد الرسول، عمر. ديوان دريد بن الصمة، دار المعارف ـ القاهرة، (د.ط).

عوض، ريتا. (ب991). بنية القصيدة الجاهلية، الصورة الثعرية لدى امرئ القيس، دار الآداب ـ بيروت، الطبعة

الاولى.

عوض، ريتا. (ب991). بنية القصيدة الجاهلية، الصورة الثعرية لدى امرئ القيس، دار الآداب، بيروت، الطبعة

الاولى.

القيسي، د. نوري حمودي. (·9V) (1). الطبيعة في الثعر الجاهلي، دار الارشاد -بيروت، الطبعة الأولى. المطلبي، د. عبد الجبار • (.91 1). مواقف في الادب والنقة، دار الحرية للطباعة ـ بغداد.

مولوي، محمد سعيد. (ع 9 (1). ديوان عنترة، تحقيق ودراسة: محمد سعيد مولوي، المكتب الاسلامي ـ القاهرة، (د.ط). ناصف، د. مصطفى. (1911). قراءة ثانية لشعرنا القيم، دار الاندلس، الطبعة الثانية.

نصبر، أمل طاهر. فاعلية المكان في بناء القصيدة عند ذي الرمة ـ مقدمة القصيدة نموذجا، جامعة الملك سعود .

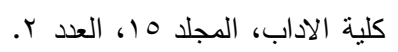


العداد الثاني والأربعون

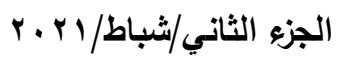
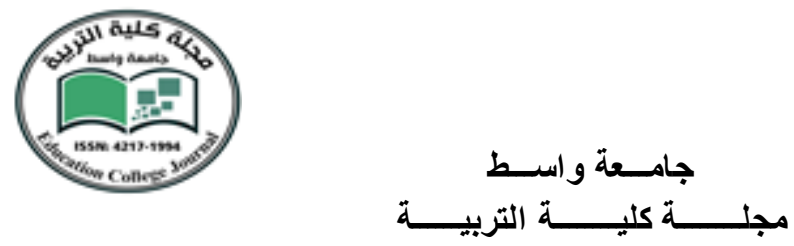

• النويهي، د. محمد. الشعر الجاهلي منهج في دراسته وتقويمه، الدار القومية للطباعة والنشر . القاهةة، (د.ط). • يعقوب، اميل بديع. (1991). ديوان عمرو بن كلثوم، دار الكتاب العربي بيروت، الطبعة الأولى.

$1 \leqslant r$ 